\title{
M. Dudek
}

AGH-University of Science and Technology, Faculty of Materials Science and Ceramics, Department of Inorganic Chemistry, Cracow, Poland

\section{COMPOSITE OXIDE ELECTROLYTES FOR ELECTROCHEMICAL DEVICES}

\begin{abstract}
This work is focused on the comparative analysis of electrical, electrochemical and mechanical properties of composite ceramic oxide electrolytes, providing a brief overview of the materials having better performance than monophase ones in various high temperature electrochemical devices such as: solid oxide fuel cells, sensors for automotive industry, oxygen probes for controlling metal processing. Introduction of $\mathrm{Al}_{2} \mathrm{O}_{3}$ inclusions into cubic yttria - zirconia solid solution (8YSZ) matrix, caused the improvement of electrical and mechanical properties compared to pure 8YSZ. The $\mathrm{Nd}_{2} \mathrm{Ti}_{2} \mathrm{O}_{7}$ secondary phase was also able to coexist with $8 \mathrm{YSZ}$ matrix and the fracture toughness $\mathrm{K}_{\mathrm{Ic}}$ of $8 \mathrm{YSZ}$ ceramics was also significantly improved by $\mathrm{Nd}_{2} \mathrm{Ti}_{2} \mathrm{O}_{7}$ addition.

Heterophase oxide ionic conductors in the system Calcium zirconate - cubic calcia zirconia solid electrolytes seem to be promising solid electrolytes for application in electrochemical probes for controlling oxygen dissolved in molten steel. The ionic conduction limit for electrolytes based on $\mathrm{CaZrO}_{3}$ is lower than that for calcia - stabilized zirconia (13CSZ). Hence $\mathrm{CaZrO}_{3}$-based materials perform better at low oxygen concentration at molten alloys.

On the other hand composite layered ceramics involving $\mathrm{Ce}_{0.8} \mathrm{Sm}_{0.2} \mathrm{O}_{2} / \mathrm{Bi}_{0.8} \mathrm{~Eb}_{0.2} \mathrm{O}_{2}$ or $\mathrm{Ce}_{0.9} \mathrm{Gd}_{0.1} \mathrm{O}_{2} / \mathrm{BaCe}_{0.8} \mathrm{Y}_{0.2} \mathrm{O}_{3} / \mathrm{Ce}_{0.9} \mathrm{Gd}_{0.1} \mathrm{O}_{1.95}$ system exhibited better electrolytic stability in gas atmospheres with low oxygen partial pressure at the temperatures $600-800^{\circ} \mathrm{C}$. These materials are successfully tested as electrolytes in solid oxide fuel cells. The gradient ceramic oxide electrolytes seems to overcome the limitation of applying them as solid electrolytes in solid oxide fuel cells for long time performance.
\end{abstract}

Key words : composite dispersed solid electrolytes, gradient ceramic electrolytes, solid oxide fuel cells (SOFC), electrochemical oxygen probes, ceria, zirconia electrolyte.

\section{INTRODUCTION}

Ceramic oxide ionic conductors have attracted much attention because of their possible application as solid electrolytes in the electrochemical devices such as: solid oxide fuel cell (SOFC), gas sensors, probes for determination of the oxygen dissolved in molten metals, oxygen pumps, thermoelectric generators, culometric timers or chemical reactors [1-3]. The major scientific applications of ionically conducting solids are electrolytes in galvanic cells, designed to provide fundamental thermodynamic and kinetic data [4-7]. Solid electrolytes satisfy a large number of requirements: fast ionic transport, negligible electronic conduction, and thermodynamic stability over a wide range of temperature and oxygen partial pressure. In addition, they must have a thermal expansion value compatible with that of electrodes and other construction materials, 
suitable mechanical properties and negligible interaction with electrode materials under operation conditions [8-9]. Due to a growing interest in environmentally friendly and energy - saving technologies, developments in the field of SOFC and other high temperature electrochemical devices have been considerably intensified in the last 15 years. In particular, some novel oxygen ionic conductors have been reported in the literature, including $\mathrm{LaGaO}_{3}, \mathrm{NdAlO}_{3}$ - based perovskites, derivatives of $\mathrm{Bi}_{4} \mathrm{~V}_{2} \mathrm{O}_{11}$ (BIMEVOX) and $\mathrm{La}_{2} \mathrm{Mo}_{2} \mathrm{O}_{9}$ (LAMOX), several new pyrochlores with relatively high ionic transport such as $(\mathrm{Gd}, \mathrm{Ca})_{2} \mathrm{Ti}_{2} \mathrm{O}_{7}$, apatite derived from $\mathrm{Ln}_{10-\mathrm{x}} \mathrm{Si}_{6} \mathrm{O}_{26}$, where $\mathrm{Ln}$ is a rare earth cation [10-14].

The well-known $\mathrm{MO}_{2}(\mathrm{M}=\mathrm{Zr}$, Ce)-based solid electrolytes are still an attractive candidate to be applied in SOFC and other devices. The application of a new method for manufacturing gas-tight thin films, like (spray-pyrolyis deposition, tape-casting, spincoating, electrophoretic deposition, lithography) is one possibility of obtaining a material with sufficient ionic conductivity to be applied as solid electrolytes in electrochemical devices operating below $800^{\circ} \mathrm{C}$ [15-18].

To improve electrical and mechanical properties as well, a dispersed heterophase can be introduced into a solid electrolyte matrix [19-21]. Since the first experiments performed by Liang [22] on $\mathrm{LiI}-\mathrm{Al}_{2} \mathrm{O}_{3}$ composites, numerous studies have been performed on various solid electrolytes composites. The effect of conductivity increase was found in many systems based either on halides (eg. $\mathrm{AgCl}, \mathrm{BaF}_{2}, \mathrm{CaF}_{2}$ ) or oxides $\left(\mathrm{ZrO}_{2}, \mathrm{Ca}-\beta "-\mathrm{Al}_{2} \mathrm{O}_{3}\right)$ with alumina, titania or silica inclusions [23-26].

Generally, in the composite material, the ionic conductivity increases strongly with the concentration of the dispersed phase and then decreases when after reaching maximum. To interpret the results of conductivity measurements in those composites, several theoretical models were proposed. All of them assumed interactions between mobile charged defects and the surface of the dispersed inert phase, leading to space charge region with defect concentrations differing from the intrinsic bulk concentration [27-32]. Uvarov, et al. presented a model that considered the surface conductivity and the microstructure of composite solid electrolytes, and he used it to explain their electrical conduction behaviour. He was shown that enhancement in electrical conductivity for such composites strongly dependents on the sample preparation conditions, and higher conductivities are expected if a better contact between the solid electrolytes and the dispersoid can be achieved [33].

Solid electrolytes exhibit predominantly ionic conductivity only over a limited range of temperature and chemical potentials. Thus, the electrolytic conduction domain is an important factor limiting the application of these materials in electrochemical devices. Most of ionic conductors operate under a severe chemical potential gradient. Taking into consideration the functional gradient, one can design two or more layers of composite electrolytes with a better performance then for monophase materials in gas sensors, or solid oxide fuel cells [34-38].

K.T. Jacob , et al have given a general analysis of electromotive force (EMF) of a cell incorporating composition gradient solid electrolytes [39-41]. The theoretical analysis of a bilayer ceramic oxide electrolytes in solid oxide fuel cell was also considered [42]. Some experimental studies showed that solid electrolytes with gradient composition were also successfully applied for the thermodynamic data studies in $\mathrm{La}_{2} \mathrm{O}_{3}-\mathrm{ZrO}_{2}$ [43] and $\mathrm{Na}_{2} \mathrm{CO}_{3}-\mathrm{Na}_{2} \mathrm{SO}_{4}$ system [44].

The aim of this paper is to give an overview of the electrical and mechanical properties of composite oxide solid ionic conductors and their possible application as 
solid electrolytes with a better performance than monophase material in solid oxide fuel cells, electrochemical gas sensors or probes for controlling metal processing.

\section{ZIRCONIA -BAESED ELECTROLYTES}

Zirconia-yttria $\left(8 \%\right.$ mol $\mathrm{Y}_{2} \mathrm{O}_{3}$ in $\left.\mathrm{ZrO}_{2}-8 \mathrm{YSZ}\right)$ with fluorite structure is the oxygen ion conductor mostly used as a solid electrolyte in electrochemical gas sensors, probes, solid oxide fuel cells, pumps or solid galvanic cells. Due to its high values of ionic oxide conductivity, low manufacturing costs, chemical stability under oxidizing or reducing gas atmospheres [45-48].

A conventional SOFC using YSZ as a solid electrolyte requires a high operating temperature $\left(1000^{\circ} \mathrm{C}\right)$, resulting in serious problems as: chemical reaction between components, thermal degradation of materials or cracking during cycles. This implies a short service life of cell and requires expensive metallic materials for interconectors. Lowering the operation temperature of SOFC is the main goal of technology of solid fuel cells, and it constitutes a challenge for the materials under design and development [49-51].

Planar solid oxide fuel cells are currently being developed in two main geometrical variants with different structural support (Fig. 1). SOFC concepts based on electrode substrates (mostly anode) allow to reduce the electrolyte thickness to thin layers [52-55].
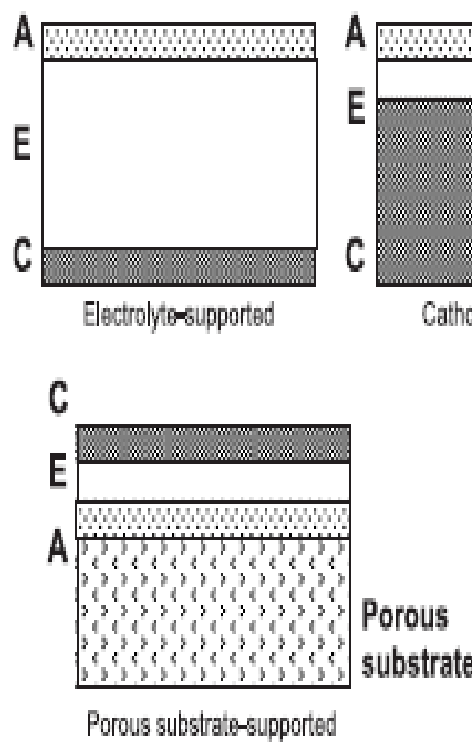

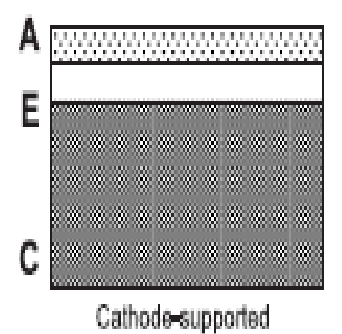

Cathoderupported

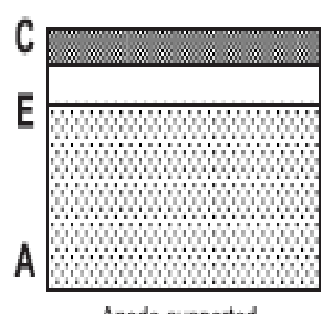

Anoderupported

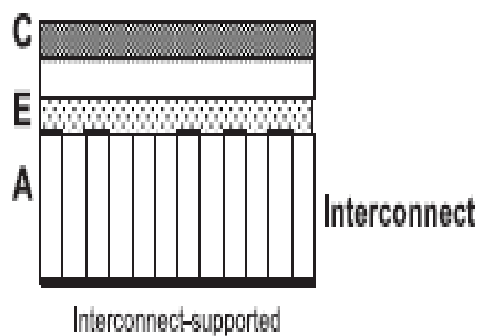

Fig 1. SOFC single cell configuration. Reprinted from [52] with permission Elsevier.

In the electrolyte supported variant, a much thicker membrane $(\sim 100-200 \mathrm{~mm})$ is required for mechanical robustness. The main advantages of electrolyte - supported cells are: a relatively strong support from dense electrolyte, lower susceptibility to failure due to anode reoxidation and cathode reduction. In this case, the cell resistance strongly depends on electrolyte thickness; the anode supported SOFC concept has the attractive advantage for intermediate temperature performance. The difference in the thermo-elastic behaviour between the individual layers in the planar SOFC cell composite generates residual stresses that can cause mechanical integrity problems. 
However, there are some specific advantages of electrolyte supported cell in respect to mechanical integrity. The electrolyte supported cell has a more or less symmetric layer structure, and thus, residual stresses generate smaller curvature, i.e the cells are essentially flat [56,57].

This consideration indicates that the application of 8YSZ in solid ionic devices means not only high conductivity, but also better mechanical properties (flexural strength and fracture toughness). The thin solid electrolyte in SOFC configuration needs to be strong and tough enough to withstand room temperature assembly stresses and to be mechanically stable for long periods at high temperatures in reducing and oxidizing atmospheres. Therefore, the enhancement of mechanical properties of the solid electrolyte is an important problem to be solved [58-61].

The electrical and mechanical properties of composites $8 \mathrm{YSZ}$ with $\mathrm{Al}_{2} \mathrm{O}_{3}$ inclusions have been studied for more than 20 years. In spite of such interest in zirconia-alumina - based composites, some results described in the paper quoted are far from being complete, and their interpretation is rather difficult Generally, samples 8 YSZ containing up to $7-9 \mathrm{wt}$. $\%$ at temperatures $200-800^{\circ} \mathrm{C}$ showed electrical conductivity values higher than those of cubic $\mathrm{ZrO}_{2}$ stabilized yttria, although in some cases a deterioration in ionic conductivity was observed. The increase in electrical conductivity of cubic zirconia-alumina particulate composites is generally attributed to the interaction between alumina and silica, which modifies interfaces and grain boundaries as a result of purification from the silica -rich glassy phase [62-64].

An addition of $\mathrm{Al}_{2} \mathrm{O}_{3}$ enhanced also the flexural strength and fracture toughness of $8 \mathrm{YSZ} / \mathrm{Al}_{2} \mathrm{O}_{3}$ composites as compared to the monophase $8 \mathrm{YSZ}$. However, some data also indicates that such an addition improves mechanical properties, but reduces electrical conductivity [65-67]. Controversial increase in flexural strength up to 480 $\mathrm{MPa}$, without changes of ionic conductivity, have also been reported [68].

Guo summarizes and analyzes the positive and negative effects of $\mathrm{Al}_{2} \mathrm{O}_{3}$ additions on the electrical properties of $\mathrm{ZrO}_{2}$. An $\mathrm{Al}_{2} \mathrm{O}_{3}$ addition may cause an increase in bulk resistivity, mainly because of formation of defect associates and insulating $\mathrm{Al}_{2} \mathrm{O}_{3}$ second-phase particles. $\mathrm{Al}_{2} \mathrm{O}_{3}$ inclusions content within the solubility limit increases the grain boundary space-charge potential, but when $\mathrm{Al}_{2} \mathrm{O}_{3}$ content is over the solubility limit; however, it scavenges the silica-reach phase from grain boundaries, thereby decreasing the grain boundary resistivity $[69,70]$.

Systematic research on the influence of both alumina content and microstructure on the electrical and mechanical properties was also reported in detail [71-73]. To visualise the influence of $\alpha-\mathrm{Al}_{2} \mathrm{O}_{3}$ inclusions on electrical conduction properties of the composites, the relative total conductivity $\left(\sigma / \sigma_{0}\right)$, where $\sigma_{0}$ is the conductivity of pure 8YSZ matrix, was plotted against the alumina content - Fig 2 - for two series of (HG) and (HA), samples. Materials originating from gamma-alumina powder were marked as $\mathrm{HG}$-series, while those prepared from alpha-alumina powder - as HA -series.

In both cases, inclusions of 7.5 wt. $\%$ of $\alpha-\mathrm{Al}_{2} \mathrm{O}_{3}$ caused the maximum enhancement in the conductivity by factors 6.5 and 13 , which depended, respectively, on the sample and microstructure. The composites obtained from gamma - aluminium powder show a higher increase in conductivity than those prepared from alpha-alumina powder. The average grain sizes of the zirconia matrix are practically the same in the (HG) and (HA) - series, whereas the average grain sizes of alumina inclusions in both series differ by a factor 2 [72]. 


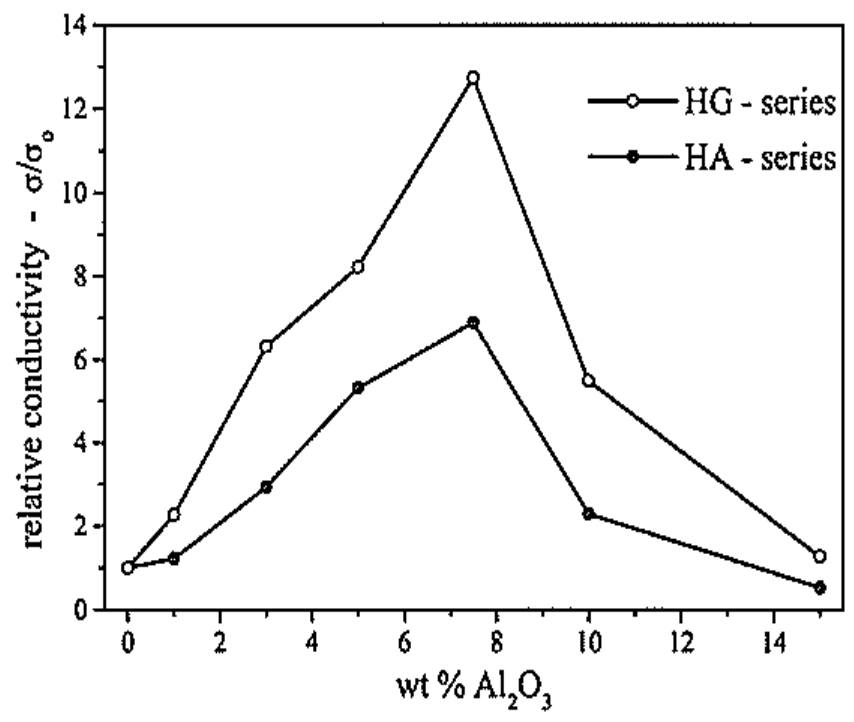

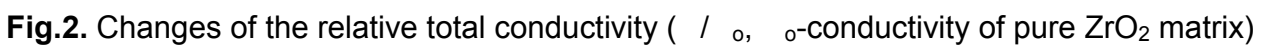
for both series as a function of alumina content at $400^{\circ} \mathrm{C}$. Reprinted from [72] with permission PTCer.

In both the series investigated, after the maximum (at higher alumina content), the conductivity value decreases rapidly. The influence of chemical composition and microstructural features on mechanical properties of cubic zirconia-alumina was also investigated. The maximum values of fracture toughness $\mathrm{K}_{\text {Ic }}$ was reached at 5 and $10 \%$ alumina inclusions for the composites of the $\mathrm{HA}$ and $\mathrm{HG}$, respectively. The highest increase in fracture toughness $\mathrm{K}_{\mathrm{Ic}}$ (up to $3.9 \mathrm{MPa} \cdot \mathrm{m}^{0.5}$ ) has been found when inclusions size was comparable to the matrix grain [73]. These results indicate that the microstructure (size of inclusions and matrix) has a strong influence on the electrical and mechanical properties.

Recently, Chan and Yang have developed a new toughening process, called piezoelectric sencondary phase toughening, in which a piezoelectric secondary phase is introduced into the ceramics matrix as a toughening agent, and the energy dissipation resulting from domain wall motion and piezoelectric effect is considered to be the toughening mechanism. The piezoelectric secondary phase toughening approach has been applied successfully to several systems: $\mathrm{BaTiO}_{3} / \mathrm{Al}_{2} \mathrm{O}_{3}, \mathrm{Nd}_{2} \mathrm{Ti}_{2} \mathrm{O}_{7} / \mathrm{Al}_{2} \mathrm{O}_{3}$ [74]. $\mathrm{Nd}_{2} \mathrm{Ti}_{2} \mathrm{O}_{7}$ as a secondary phase was able to coexist with an $8 \mathrm{YSZ}$ matrix, and the fracture toughness $\mathrm{K}_{\mathrm{Ic}}$ was scientifically improved by a $\mathrm{Nd}_{2} \mathrm{Ti}_{2} \mathrm{O}_{7}$ addition. An optimal value of $8 \mathrm{MPa} \cdot \mathrm{m}^{0.5}$ was obtained for $8 \mathrm{YSZ}$ including $15 \% \mathrm{~mol} \mathrm{Nd}_{2} \mathrm{Ti}_{2} \mathrm{O}_{7}$ composite material, and this value was 2.5 times higher that of the monophase 8 YSZ [75].

\section{CERIA -BASED ELECTROLYTES}

Ceria is a promising solid electrolyte for application in solid oxide fuel cells, onboard diagnostic sensors for monitoring hydrocarbons and other exhaust gasses at intermediate temperature range $600-800^{\circ} \mathrm{C}$ [76-80]. The primary problem encountered in using ceria-based electrolytes for IT-SOFC is the partial reduction of ceria in fuel atmospheres [81-85]. This results in n-type electronic conductivity, causing partial internal electronic short circuits in the cell. It also results in an expansion of the crystal 
lattice, which leads to mechanical degradation either inside the electrolyte or at the electrolyte - electrode interface. It has been reported that the reduction of ceria can be neglected at a lower temperature - around $600-700^{\circ} \mathrm{C}$. However, such low temperatures are not suitable for singly doped ceria $-\mathrm{Ce}_{1-\mathrm{x}} \mathrm{M}_{\mathrm{x}} \mathrm{O}_{2}(\mathrm{M}=\mathrm{Sm}, \mathrm{Gd}, \mathrm{Y}$ where $\mathrm{x}=0.15$ $0.20)$ as SOFC's electrolyte, due to high resistivity of this material [86,87].

A structural modification of ceria solid solutions is one among the possible ways to improve their electrical conductivity $[88,89]$. Co-doped ceria of $\mathrm{Ce}_{0.85} \mathrm{Gd}_{0.15-\mathrm{x}} \mathrm{Sm}_{\mathrm{x}} \mathrm{O}_{2}$, wherein $0.05 \leq \mathrm{x} \leq 0.1$, showed much higher ionic conductivity at $500-700^{\circ} \mathrm{C}$. These materials seem to be more fitting electrolyte materials for IT-SOFC [90]. Maricle, et al. also reported that due to co-doping small quantities of praseodymium in $\mathrm{Ce}_{1-\mathrm{x}} \mathrm{Gd}_{\mathrm{x}} \mathrm{O}_{2}$ solid solution, the application region is shifted by two orders to magnitude to lower oxygen partial pressure [91]. The co-doping ceria with calcia and samaria also leads to an improvement in their electrolytic properties when compared to only samaria-doped ceria $[92,93]$.

The application of the layered materials or functionally gradient oxide electrolytes is another possible way to improve their performance in a classical solid oxide fuel cell or single-chamber cell [94-96].Ceria-zirconia sandwich structured composite film electrolytes were designed in order to offer high ionic and electronic conductivity films. Calculations of oxygen potential profile in the composite film electrolyte indicate that $8 \mathrm{YSZ}$ thin films kill the electronic current of ceria without affecting ionic conductivity. Composite films were successfully prepared in a co-firing process. De-lamination between yttria-doped zirconia (YSZ) or gadolina doped ceria (GDC) layers was overcome by the formation of a solid solution phase at the interface of the two films. The resultant composite films showed not only poor electrical conductivity as compared to theoretical values, but also poor mechanical strength values and lattice expansion in reducing atmospheres. The problems of improved mechanical properties still need a solution [97].

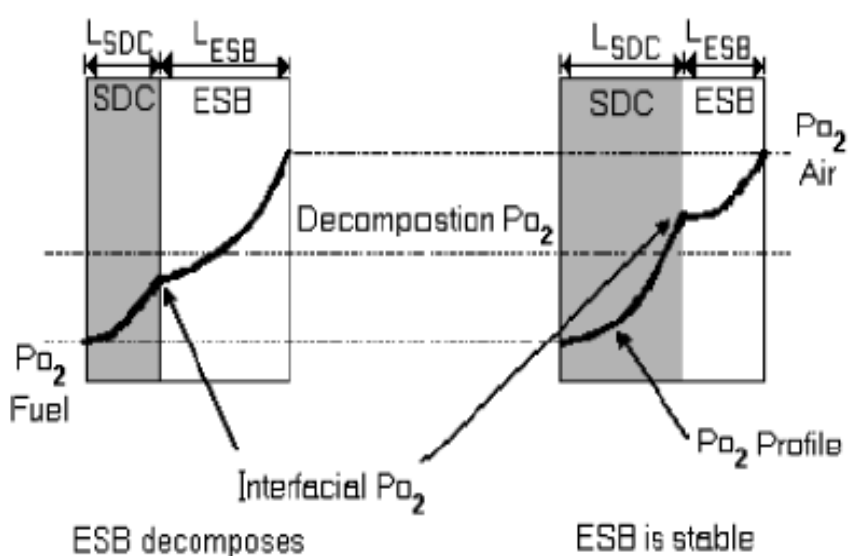

Fig. 3. Conceptual representation of an erbia-stabilized bismuth oxide/ samaria-doped ceria (ESB/SDC) bilyaer electrolyte showing the effect of relative thickness on interfacial $p_{\mathrm{O}_{2}}$ Reproduced from [98] with permission ACS

The bilayer electrolyte composed of two highly conductive oxide $\left(\mathrm{Er}_{2} \mathrm{O}_{3}\right)_{2}\left(\mathrm{Bi}_{2} \mathrm{O}_{3}\right)_{0.3}(\mathrm{ESB})$ on the high $p_{\mathrm{O}_{2}}$ side and $\left(\mathrm{Sm}_{2} \mathrm{O}_{3}\right)_{0.1}\left(\mathrm{CeO}_{2}\right)_{0.8}(\mathrm{SDC})$ on the low $p_{\mathrm{O}_{2}}$ (Fig. 3) seems to be a promising solution [98]. The advantage of this design over the SDC/YSZ bilayer is that SDC and ESB are both conductive enough to serve as intermediate IT-SOFC electrolytes. Thus, at worst, and ESB/SDC bilayer SOFC should 
have the conductivity of SDC but with an improved efficiency since the electronic flux barrier prevents the ESB layer from decomposition at very low $p_{\mathrm{O}_{2}}$ as in shown in Fig.4 SDC can act both as electrolyte (ionic) and anode (mixed ionic-electronic) depending on local $p_{\mathrm{O}_{2}}$. Therefore, a higher $\mathrm{t}_{\mathrm{i}}$ can be obtained by bilayer ESB/SDC electrolytes than with SDC. These results also indicate higher values of electrical conductivity and better performance in solid oxide fuel cells. Fig.4 shows a comparison of cell performance of SDC and SDC/ESB electrolytes at $800^{\circ} \mathrm{C}$. Cells are $0.8 \mathrm{~mm}$ thick with a Pt- $\mathrm{H}_{2} / \mathrm{H}_{2} \mathrm{O}$ anode and an $\mathrm{Au}-\mathrm{O}_{2}$ cathode.

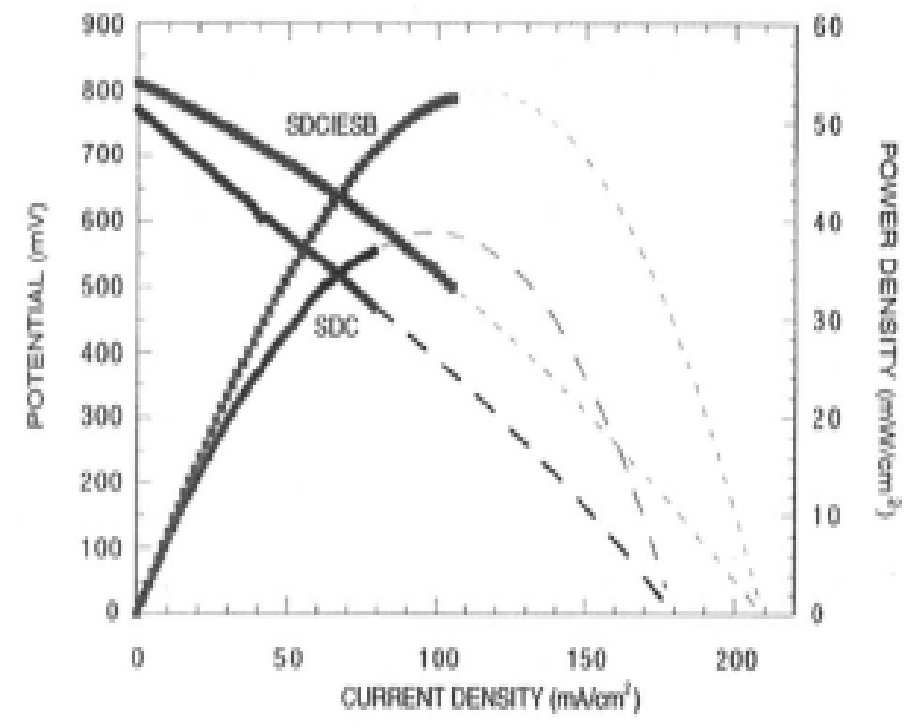

Fig. 4. Comparison of cell performance of SDC and SDC/ESB electrolytes at $800^{\circ} \mathrm{C}$. Cells are $0.8 \mathrm{~mm}$ thick with $\mathrm{Pt}-\mathrm{H}_{2} / \mathrm{H}_{2} \mathrm{O}$ anode and $\mathrm{Au}-\mathrm{O}_{2}$ cathode. Reproduced from [99] with permission ECS

The increase in values of OCV and power density solid oxide fuel cell with SDC/ESB electrolyte as compared to only SDC electrolyte was observed [99].

The incorporation of a protonic $\mathrm{BaCeO}_{3}$-based ion conductor into the composite electrolyte structure also leads to a better performance of the electrolyte in SOFC. The multilayered $\mathrm{Ce}_{0.9} \mathrm{Gd}_{0.1} \mathrm{O}_{2} / \mathrm{BaCe}_{0.8} \mathrm{Y}_{0.2} \mathrm{O}_{3-\alpha} / \mathrm{Ce}_{0.9} \mathrm{Gd}_{0.1} \mathrm{O}_{2}$ (GDC/BCY/GDC) electrolyte on a Ni-Ce ${ }_{0.8} \mathrm{Sm}_{0.2} \mathrm{O}_{1.9}$ anode-support was prepared by tape-casting method. The overall electrolyte thickness ranged from 30 to $35 \mu \mathrm{m}$, including $3 \mu \mathrm{m}$ thick BCY layer. The designed composite material was also successfully tested as ceramic electrolyte in solid oxide fuel cells at the temperature $500-700^{\circ} \mathrm{C}$, and reached an $\mathrm{OCV}$ of $846-1024 \mathrm{mV}$, which was higher than for a single layer GDC electrolyte under the same conditions. The investigated composite electrolyte also may be applied as a membrane with direct methane operated SOFC or single chamber fuel cell [100].

\section{$\mathrm{CaZrO}_{3}$ - BASED ELECTROLYTES FOR OXYGEN ELECTROCHEMICAL PROBES}

Electrochemical oxygen sensors based on partially or fully $\left(\mathrm{Y}_{2} \mathrm{O}_{3}, \mathrm{CaO}, \mathrm{MgO}\right)$ stabilized zirconia have been developed, and they are used in steel making, nickel and copper refining processes. Although they are single - reading probes, these sensors 
achieved high industrial standard worldwide. However, there is necessity to improve their performance $[101,102]$. Up to now no suitable oxygen probes for one-line measurements (especially in steel production) have been developed. Steels with very low oxygen content can establish an oxygen partial pressure that is low enough for significant electronic conductivity to occur in zirconia. Significant electronic conductivity in the electrolyte can lead to an erroneous sensor output [103]. One area of improving the performance of electrochemical probes with respect to applying them in on-line measurements in metallurgy is the substitution of zirconia - based solid electrolyte by an alternative ceramic material, which remains a pure oxygen ion conductor to lower oxygen pressure. Good mechanical properties, thermal shock resistance and thermodynamic stability are also required for such applications.

The ionic conduction limit for yttria-doped thoria (YDT) is lower; therefore, these electrolytes perform better at a low oxygen activity. Due to radioactivity and costs, thoria or hafnia-based electrolytes are rather rarely applied in steel industry $[104,105]$.

Calcium zirconate - composite materials with cubic calcia-zirconia solid solution as inclusions seem also to be appropriate solid oxide electrolytes for high temperature application [106-108]. Fig.5 illustrates changes of the $\mathrm{CaZrO}_{3}$ weight fraction, determined by the Rietveld refinement as function of calcia content in samples investigated. Orthoromic $\mathrm{CaZrO}_{3}$ as only singly phase was detected by XRD method in the samples containing from 0.50 to $0.515 \mathrm{~mol}$ fraction of $\mathrm{CaO}$. Changes of the phase content in the $\mathrm{CaZrO}_{3}$-based materials strongly depended on oxides being in excess. Even in the sample with the smallest $\mathrm{ZrO}_{2}$ excess a second phase of cubic calcia - zirconia solid solution was observed. In this way composite materials in the system $\mathrm{CaZrO}_{3}$-cubic calcia-zirconia solid solutions could be obtained [109, 110].

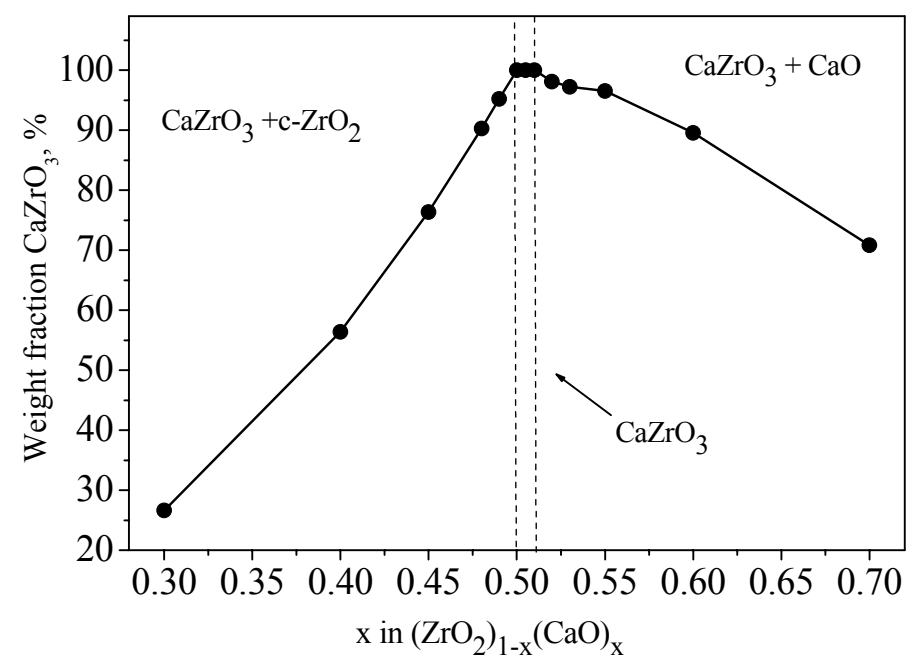

Fig 5. $\mathrm{CaZrO}_{3}$ weight fraction as a function of initially assumed calcia to zirconia molar ratio [110].

Electrical properties of $\mathrm{CaZrO}_{3}$-based materials, calcia stabilized zirconia and thoria-based electrolytes in the temperature range $200-1600^{\circ} \mathrm{C}$ are listed in table 1 . The values of electronic conduction $P_{e}^{\prime}$ (defined as the oxygen partial pressure at which the ionic and $\mathrm{n}$ - type electronic conductivities are equal) are also given. 
Table 1. Electrical properties of $\mathrm{CaZrO}_{3}$-based materials, calcia stabilized zirconia and thoria-based electrolytes in the temperature range $1000-1600^{\circ} \mathrm{C}$. Data from $[111,112]$.

\begin{tabular}{|c|c|c|c|c|}
\hline \multirow{2}{*}{$\begin{array}{c}\mathrm{x} \text { in } \\
(\mathrm{CaO})_{\mathrm{x}}\left(\mathrm{ZrO}_{2}\right)_{1-\mathrm{x}}\end{array}$} & \multicolumn{2}{|c|}{$\sigma(\mathrm{S} / \mathrm{cm})$} & \multirow{2}{*}{$\begin{array}{c}\mathrm{Ea}, \\
\mathrm{eV}\end{array}$} & $\begin{array}{c}P_{e}^{\prime}(\mathrm{bar}), \mathrm{t}_{\text {jon }}=0.5 \\
\text { at } 1600^{\circ} \mathrm{C}\end{array}$ \\
\hline 0.5 & $1.30 \cdot 10^{-6}$ & $5.1 \cdot 10^{-3}$ & 2.25 & \\
\hline 0.48 & $6.20 \cdot 10^{-6}$ & $2.8 \cdot 10^{-2}$ & 1.37 & $1.5 \cdot 10^{-18}$ \\
\hline 0.45 & $4.60 \cdot 10^{-5}$ & $5.8 \cdot 10^{-2}$ & 1.34 & $1.4 \cdot 10^{-18}$ \\
\hline 0.30 & $4.14 \cdot 10^{-3}$ & $3.2 \cdot 10^{-1}$ & 1.33 & \\
\hline $0.13(13 \mathrm{CSZ})$ & $5.1 \cdot 10^{-2}$ & $6.0 \cdot 10^{-1}$ & 0.72 & $1.2 \cdot 10^{-15}$ \\
\hline $\begin{array}{c}8 \% \mathrm{~mol}_{2} \mathrm{O}_{3} \\
\text { in } \mathrm{ThO}_{2}(8 \mathrm{YDT})\end{array}$ & $2.1 \cdot 10^{-2}$ & $1.3 \cdot 10^{-1}$ & 0.78 & $1.2 \cdot 10^{-18}$ \\
\hline
\end{tabular}

The presence of calcia - stabilized zirconia as a second phase in $\mathrm{CaZrO}_{3}$-based materials led to improvement of electrical conductivity, due to its better conductive properties compared to $\mathrm{CaZrO}_{3}$ electrolyte. The $13 \mathrm{CSZ}$ or $8 \mathrm{YDT}$ - based electrolytes exhibit comparatively high values of electrical conductivity $\sigma$ from 0.13 to $0.60(\mathrm{~S} / \mathrm{cm})$ at $1600^{\circ} \mathrm{C}$. The electrical conductivity of solid oxide electrolytes based on $\mathrm{CaZrO}_{3}$ is about one order of magnitude lower but still sufficient to apply them as components of electrochemical devices. In order to calculate the oxygen activity in steel melt from EMF measured a knowledge of the parameter $P_{e}^{\prime}$ is essential $[113,114]$. The $\mathrm{CaZrO}_{3}$ based materials exhibited lower values of electronic conduction than that of monophase $(\mathrm{CaO})_{0.13}\left(\mathrm{ZrO}_{2}\right)_{0.87}$ electrolyte. This might indicate a better electrochemical properties of $\mathrm{CaZrO}_{3}$ - composite electrolytes at lower oxygen partial pressure at high temperature applications [115].

The composite $\left(\mathrm{ZrO}_{2}\right)_{0.55}(\mathrm{CaO})_{0.45}$ was tested as solid electrolyte in electrochemical oxygen probes for liquid iron or steel including 0.0025 to $0.20 \%$ dissolved oxygen at $1600^{\circ} \mathrm{C}$. The recorded EMF values for galvanic cell involving composite electrolyte-based on $\mathrm{CaZrO}_{3}$ were close to theoretical EMF values calculated from Nernst equation. The obtained results were compared with EMF values measured in the same conditions with electrochemical probes including monophase $13 \mathrm{CSZ}$. As opposed to electrochemical probes with only calcia - zirconia solid electrolyte, the values of dissolved oxygen determined by means of electrochemical probes with $\mathrm{CaZrO}_{3}$ electrolyte did not require any corrections to calculations so as to regard partial electronic conductivity. The composite material performs better than only $13 \mathrm{CSZ}$ in solid galvanic cell with low oxygen partial pressure at high temperatures. The chemical stability of $\mathrm{CaZrO}_{3}$ - based electrolytes in liquid metals such as nickel, copper or iron, was also investigated. Microstructural observations carried out with scanning microscopy and EDS analysis did not reveal any products of the reaction between $\mathrm{CaZrO}_{3}$-based samples and metallic melts. The highest thermal resistance in the cyclic temperature conditions and good thermal resistance render the prepared material to be a promising electrolyte for metallurgical application and other application in low oxygen partial pressure [116].

\section{ACKNOWLEDGMENT}

This work was carried out under contracts no 3T08D0 1926 with the Polish Scientific Research Committee (2004 -2007). 


\section{REFERENCES}

1. Advances in Ceramics, Science and Technology of Zirconia, tom 1-5, 19821993.

2. Knauth P, Tuller H, Solid State Ionics: Roots, Status and Future Prospects, Journal of the American Ceramic Society 85 (2002) pp. 1654-80.

3. Fergus J. W, Electrolytes for solid oxide fuel cells, Journal of Power Sources 162(2006)pp. 30-40.

4. Kiukola K, Wagner $\mathrm{C}$, Measurements on galvanic cells involving solid oxide electrolytes, Journal of the Electrochemical Society 104 (1957) pp.379-387.

5. Pratt T, Application of solid electrolyte in thermodynamic studies, Metallurgical Transaction, 21A, pp. 1990-1223.

6. Róg G, Kozłowska-Róg A, Dudek M, The standard Gibbs free energy of calcium chromium (III) oxide in the temperature range (1073-1273)K Journal of Chemical Thermodynamics 39 (2007) pp. 275-278.

7. Kopyto M, Fitzner K, Gibbs energy of formation of $\mathrm{Cu}_{2} \mathrm{Ln}_{2} \mathrm{O}_{5}(\mathrm{Ln}=\mathrm{Yb}, \mathrm{Tm}$, Er, Ho, Dy) and $\mathrm{CuGd}_{2} \mathrm{O}_{4}$,Journal of Materials Science 31, (1996), pp.27972800.

8. Haile S., Materials for fuel cells, Materials Today 6 (2003) pp. 24-29.

9. Pluschkell W, Electronic conduction in the solid electrolyte of oxygen concentration, Archiv für das Eisenhuttenwesen 46 (1975) pp. 11-18.

10. Ishihara $\mathrm{T}$, Masuda $\mathrm{H}$, Takaita $\mathrm{Y}$, Doped $\mathrm{LaGaO}_{3}$ perovskite type oxides as a new oxide ion conductors, Journal of the American Ceramic Society 116 (1994) pp. 3801-3806.

11. Manthiram A, Kuo J, and Goodneough J, Characterization of oxygen-deficient perovskites as oxide ion electrolytes Solid State Ionics 62(1993) pp. 225-234.

12. Kato H., Kudo T, Naito H., Yugami H., Electrical conductivity of Al-doped $\mathrm{La}_{1-\mathrm{x}} \mathrm{Sr}_{\mathrm{x}} \mathrm{ScO}_{3}$ perovskite-type oxides as electrolyte materials for low-temperature SOFC Solid State Ionics 159(2003) pp.217-222.

13. Kutty K.V, Mathews C.K, Rao C.T and Varadaraju U. T, Oxide ion conductivity in some substituted rare earth pyrozironiates, Solid State Ionics 80 (1995)pp. 99110.

14. Arikawa H, Nishiguchi H., Ishihara H, Takita Y, Oxide ion conductivity in Srdoped $\mathrm{La}_{10} \mathrm{Ge}_{6} \mathrm{O}_{27}$ apatite oxide Solid State Ionics 136-137(2000) pp.31-37.

15. Zhang Y, Huang X, Lu Z, Liu Z, Ge X, Xu J, Xin X, Sha X, Su W, A novel method for fabrication of $\mathrm{Y}_{2} \mathrm{O}_{3}$-stabilized $\mathrm{ZrO}_{2}$ electrolyte films, Journal of the American Ceramic Society 89 (2006) pp.2304- 2307.

16. Gaudon M, Djurado E, Menzler N, Morphology and sintering behaviour of yttria stabilised zirconia (8-YSZ) powders synthesised by spray pyrolysis, Ceramic International 30 (2004) pp. 2295-2303.

17. Peng R, Xia Ch, Peng D, Meng G, Effect of powder preparation on $\left(\mathrm{CeO}_{2}\right)_{0.8}\left(\mathrm{Sm}_{2} \mathrm{O}_{3}\right)_{0.1}$ thin film properties by screen-printing, Materials Letters 58 (2004) pp.604-608. 
18. Cheng J., Zha S, Huang J, Liu X, Meng G, Sintering behaviour and electrical conductivity of $\mathrm{Ce}_{0.9} \mathrm{Gd}_{0.1} \mathrm{O}_{1.95}$ powder prepared by the gel-casting process Materials Chemistry and Physics 78 (2003) pp.791-795.

19. Shai K., Wagner J., Enhanced ionic conduction in dispersed solid electrolyte systems (DSES) and/or multiphase systems: $\mathrm{AgI}-\mathrm{Al}_{2} \mathrm{O}_{3}, \mathrm{Agl}-\mathrm{SiO}_{2}, \mathrm{AgI}-\mathrm{Fly}$ ash, and AgI-AgBr Journal of Solid State Chemistry 42 (1982) pp.107-119.

20. Knauth P, Debierre J, Albient G, Electrical conductivity of model composites of an ionic conductor $(\mathrm{CuBr})$ and an insulator $\left(\mathrm{TiO}_{2}, \mathrm{Al}_{2} \mathrm{O}_{3}\right)$ : experiments and percolation-type model, Solid State Ionics 121 (1999), pp.101-106.

21. Fuijtsu S., Koumoto M., Yanagida H, Kanazawa T, Enhancement of ionic conduction in $\mathrm{CaF}_{2}$ and $\mathrm{BaF}_{2}$ by dispersion of $\mathrm{Al}_{2} \mathrm{O}_{3}$, Journal of Materials Science 22 (1985) pp. 2103-2109

22. Liang $\mathrm{C}$, Conduction characteristic of the lihium iodide-aluminium oxide solid electrolytes, Journal of the Electrochemical Society 120 (1973) pp.1289-92.

23. Jacob K.T, Shukla A, Kinetic decomposition of $\mathrm{Ni}_{2} \mathrm{SiO}_{4}$ in oxygen potential gradients Journal of Materials Research 2 (1987) pp.338-342.

24. Vaidehi N, Akila R, Shukla A, Jacob K.T, Enhanced ionic conduction in dispersed solid electrolyte systems $\mathrm{CaF}_{2}-\mathrm{Al}_{2} \mathrm{O}_{3}$ and $\mathrm{CaF}_{2}-\mathrm{CeO}_{2}$ Materials Research Bulletin 21(1986) pp. 909-916.

25. Bućko M, Róg G; Electrical conductivity in $\alpha-\mathrm{Al}_{2} \mathrm{O}_{3}-\mathrm{Ca}-\beta-\mathrm{Al}_{2} \mathrm{O}_{3}$ system; in Fourth Euro-Ceramics, Proceedings of the Fourth European Ceramic Society Conference, Riccione '95, vol.5 Electroceramics; ed.G.Gusmano, E.Traversa; Gruppo Editoriale Faenza Editrice, 1995, pp. 365-372.

26. Bućko M, Róg G; Properties of $\mathrm{ZrO}_{2}-\mathrm{Ca}-\beta-\mathrm{Al}_{2} \mathrm{O}_{3}$ composites; in Fourth EuroCeramics, Proceedings of the Fourth European Ceramic Society Conference, Riccione '95, vol.5 Electroceramics; ed.G.Gusmano, E.Traversa; Gruppo Editoriale Faenza Editrice, 1995, pp. 421-426.

27. Wagner J, Transport in compounds containing a dispersed second phase, Materials Research Bulletin, 15 (1980) pp.1690-1701;

28. Meier J, Defect chemistry and conductivity effects in heterogeneous solid electrolytes Journal of the Electrochemical Society 134 (1987) pp.1524-35.

29. Jamnik J., Meier J., Defect chemistry and chemical transport involving interfaces, Solid State Ionics 119 (1999) pp. 191-198.

30. Dudney N, Effect of interfacial space - charge polarization on the ionic conductivity of composite electrolytes, Journal of the American Ceramic Society 68 (1985) pp.538-45.

31. Bunde A., Dieterich W, Percolation in composites, Journal of Electroceramics 5(2000) pp. 81-92.

32. Knauth, P, Ionic Conductor Composites: Theory and Materials, Journal of Electroceramics 5 (2000) pp.111-125.

33. Uvarov N, Iusupov V, Sharama V, Shukla K, Effect of morphology and particle size on the ionic conductivities of composite solid electrolytes, Solid State Ionics 51 (1992) pp.41-52.

34. Yahiro H, Baba Y, Eguchi K, Arai H, High temperature fuel cell with ceriayttria solid electrolyte, Journal of the Electrochemical Society 135(1988) pp. 2077-2081. 
35. Bi Z, Yi B, Wang Z, Dong Y, Wu H, She Y, Cheng M, A high-performance anode-supported SOFC with LDC-LSGM bilayer electrolytes, Electrochemical and Solid State Letters 7 (2004) pp.105-107.

36. Wachsman E. D, Functionally gradient bilayer oxide membranes and electrolytes Solid State Ionics 152-153(2002)pp.657-662.

37. Peters A, Korte C, Hesse D, Zakharov N, Janek J, Ionic conductivity and activation energy for oxygen ion transport in superlattices -The multilayer system CSZ $\left(\mathrm{ZrO}_{2}+\mathrm{CaO}\right) / \mathrm{Al}_{2} \mathrm{O}_{3}$ Solid State Ionics 178 (2007) pp. 67-76.

38. S.H. Chan, X.J Chen, K.A Khor, A simple bilayer electrolyte model for solid oxide fuel cells, Solid State Ionics 158(2003) pp.29-43.

39. Jacob K.T, Mukhopadhyay S, Shukla A, Gradient solid-electrolyte for use with dissimilar gas electrodes, Solid State Ionics 62 (1993) pp. 27-33;

40. Mukhopadhyay S, Jacob K.T, Theoretical analysis of the electromotive force of a cell incorporating a composition gradient solid electrolyte Journal of the Electrochemical Society 142 (1995) pp 161- 165.

41. Mukhopadhyay S, Jacob K.T, Thermodynamic study of mixed anionic solid solutions using gradient solid electrolytes, System $\mathrm{K}_{2} \mathrm{CO}_{3}-\mathrm{K}_{2} \mathrm{SO}_{4}$., Journal of the Electrochemical Society 140 (1993) pp. 2629-2733.

42. Virkar A, Theoretical analysis of solid oxide fuel cells with two-layer composite electrolytes: electrolytes stability, Journal of the Electrochemical Society 138 (1991) 1481-1487.

43. Jacob K.T, Dasgupta N, Waseda Y, Composition-graded solid electrolyte for determination of the Gibbs energy of formation of lanthanum zirconate Journal of the American Ceramic Society 81 (1998) pp.1926-1930.

44. Mukhopadhyay S., Jacob K.T, Gradient solid electrolytes for thermodynamic measurements: system $\mathrm{Na}_{2} \mathrm{CO}_{3}-\mathrm{Na}_{2} \mathrm{SO}_{4}$, Metallurgical and Materials Transactions 25A (1994)pp. 173-181.

45. Strickler D, Carlson W, Ionic conductivity of cubic solid solutions in the system $\mathrm{CaO}-\mathrm{Y}_{2} \mathrm{O}_{3}-\mathrm{ZrO}_{2}$ Journal of the American Ceramic Society 47 (1964) pp.122127.

46. Mori T, Drennan J, Lee Y, Li J, Ikegami T, Improving the ionic conductivity of yttria-stabilised zirconia electrolyte materials, Solid State Ionics 154155(2002)pp. 529-533.

47. Bartolomeo E, Grilli M, YSZ-based electrochemical sensors: From materials preparation to testing in the exhausts of an engine bench test, Journal of the European Ceramic Society 25 (2005) pp.2959-2964.

48. Kwon O, Choi G, Electrical conductivity of thick film YSZ Solid State Ionics 177 (2006) pp. 3057-3062.

49. Minh N, Ceramic fuel cells, Journal of the American Ceramic Society 76 (1993) pp.563-588.

50. Molenda J, High - temperature solid oxide fuel cells. New Trends in materials research, Materials Science-Poland 24 (2006) pp.5-11.

51. Kharton V, Fiueiredo M, Navarro L, Naumovich E, Kovalevsky A,Yaremchenko A, Viskup A, Carneiro A, Margues A, Frade J, Ceria -based materials for solid oxide fuel cells, Journal of Materials Science 36 (2001) pp. 1105-1117. 
52. Minh N Q, Solid oxide fuel cell technology-features and applications Solid State Ionics 174 (2004) pp. 271-277.

53. Besra L, Compson Ch, Liu M, Electrophoretic deposition of YSZ particles on nonconducting porous $\mathrm{NiO}$-YSZ substrate for solid oxide fuel cells applications, Journal of the American Ceramic Society 89 (2006) pp. 3003-3009.

54. Matsuda M, Hosomi T, .Murata K, .Fukui T, Miyake M, Fabrication of bilayered YSZ/SDC electrolyte film by electrophoretic deposition for reducedtemperature operating anode-supported SOFC, Journal of Power Sources 165 (2007) pp. 102-107.

55. Krzystek K, Krauz M, Rak Z Wytwarzanie ogniw paliwowych stałotlenkowych, Polski Biuletyn Ceramiczny 84(2004) pp. 307-312.

56. Fischer W, Malzbender J, Blass G, Steinbrech R, Residual stresses in planar solid oxide fuel cells Journal of Power Sources 150 (2005)pp. 73-77.

57. Malzbender J, Steinbrech R.W, Fracture test of thin sheet electrolytes for solid oxide fuel cells, Journal of the European Ceramic Society 27 (2007) pp. 25972603.

58. Abraham I, Gritzner G, Powder preparation, mechanical and electrical properties of cubic zirconia ceramics Journal of the European Ceramic Society 16 (1996) pp.71-77.

59. Selcuk A, Atkinson A, Elastic properties of ceramic oxides used in solid oxide fuel cells (SOFC) Journal of the European Ceramic Society 17 (1997) pp.15231532.

60. Adams J, Ruth R, Mazdiyasni K, Young's modulus, flexural strength, and fracture of yttria-stabilized zirconia versus temperature Journal of the American Ceramic Society 80 (1997)pp. 903-908.

61. Susnik D, Holk J, Hrovat M, Zupancic S, Influence of alumina addition on characteristics of cubic zirconia Journal of Materials Science Letters 16 (1997) pp.1118-1121.

62. Yuzaki A, Kishimoto A, Effects of alumina dispersion on ionic conduction of toughened zirconia based composite Solid State Ionics 116(1999) pp.47-51.

63. Guo X, Tang Ch, Yuan R, Grain boundary ionic conduction in zirconia-based solid electrolyte with alumina addition, Journal of the European Ceramic Society 15 (1995)pp.25-32.

64. Butler E, Drennan J, Microstructural analysis of sintered high-conductivity zirconia with $\mathrm{Al}_{2} \mathrm{O}_{3}$ additions,Journal of the American Ceramic Society 65 (1982) pp. 474-480.

65. Feighery A., Irvine T, Effect of alumina additions upon electrical properties of 8 mol.\% yttria-stabilised zirconia, Solid State Ionics 121(1999) 209-216.

66. Mori M, Abe T,Itoh H, Yammato O, Takeda Y, Kawahara T, Cubic-stabilized zirconia and alumina composites as electrolytes in planar type solid oxide fuel cells Solid State Ionics 74 (1994) pp. 157-162.

67. Kwon N,H, Kim G, H, Song H, S, Lee L, H, Synthesis and properties of cubic zirconia-alumina composite by mechanical alloying, Materials Science and Engineering A 299 (2001) pp.185-194. 
68. K. Oe, K. Kikkawa, A. Kishimoto, Y. Nakamura, H. Yanagida, Toughening of ionic conductive zirconia ceramics utilizing a nonlinear effect, Solid State Ionics 91 (1996) 131-136.

69. X. Guo, R. Yuan, Roles of alumina in zirconia-based solid electrolyte, Journal of Materials Science 30 (1995)pp.923-331.

70. X. Guo, Roles of alumina in functional ceramics, Journal of the American Ceramic Society 86(2003) pp. 1867-73.

71. Bućko M, Selected aspects of conductivity in heterophase ionic conductors, Polish Ceramic Bulletin 66 (2001),pp.547-554.

72. Bućko M, Ionic conductivity of alumina - zirconia composites, Polish Ceramic Bulletin 61 (2000), pp. 95-102.

73. Bućko M, Pyda W, Effect on inclusion size on mechanical properties of alumina toughened cubic zirconia ,Journal of Materials Science 40 (2005) pp.5191-5198.

74. Chen X, Yang B, A new approach for toughening of ceramics Materials Letters 33 (1997) pp. 237-240.

75. Liu X, Chen X, Toughening of $8 Y-F S Z$ ceramics by neodymium titanate secondary phase Journal of the American Ceramic Society 88 (2005) pp. 456558.

76. Milliken Ch, Guruswamy S, Khandkar A, Properties and performance of cation - doped electrolyte materials in solid oxide fuel cell application. Journal of the American Ceramic Society 85 (2002) pp. 2479-86.

77. Lu C, Worell W, Gorte R, Vohs J, SOFCs for direct oxidation of hydrocarbons fuels with samaria - doped ceria electrolyte, Journal of the Electrochemical Society 150 (2003) pp.354-358.

78. Zhu S Xia Ch, Meng G, Effect of Gd ( $\mathrm{Sm})$ doping on properties of ceria electrolyte for solid oxide fuel cells, ,Journal of Power Sources 115 (2003) pp. 44-48.

79. Mukundan E, Brosha E, Brown D, Garzon F, Ceria-electrolyte-based mixed potential sensors for the detection of hydrocarbons and carbon monoxide, Electrochemical and Solid State Letters 2 (1999) pp. 412-414.

80. Dudek M, Molenda J, Preparation and properties of $\mathrm{CeO}_{2}$-based electrolytes, Polish Bulletin Ceramic 84 (2004) pp. 177-182.

81. Xiong Y, Yamaji K, Horita T, Sakai N, Yokokawa H, Hole and electron conductivity of $20 \% \mathrm{~mol} \mathrm{ReO}_{1.5} \mathrm{Re}=\mathrm{Yb}, \mathrm{Gd}, \mathrm{Sm}, \mathrm{Y}, \mathrm{Nd}$, La Journal of the Electrochemical Society 151 (2004),pp. 407- 412.

82. Xia Ch, Liu M, Low-temperature SOFCs-based on $\mathrm{Ce}_{0.9} \mathrm{Gd}_{0.1} \mathrm{O}_{2}$ fabricated by dry pressing, Solid State Ionics 144 (2001) 249-255.

83. Sameshima S, Hirata Y, Ehira Y, Structural change in Sm- and Nd-doped ceria under a low oxygen partial pressure, Journal of Alloys and Compounds 408-412 (2006) pp. 628-631.

84. Abrantes J, Perez - Coll D, Nuntez P, Frade J, Electronic transport in $\mathrm{Ce}_{0.8} \mathrm{Sm}_{0.2} \mathrm{O}_{1.9}$ samples, Electrochimica Acta 48 (2003) pp. 2761-2766.

85. Inaba H, Tagawa H, Ceria -based solid electrolytes, Solid State Ionics 83 (1996)pp.1-16. 
86. Doshi R, Richards V, Carter J, Wang X, Krumpelt M, Development of solidoxide fuel cells that operate at $500^{\circ} \mathrm{C}$, Journal of the Electrochemical Society 146 (1999)pp.1273-1278.

87. Matsui T, Inaba M, Mineshige A, Ogumi Z, Electrochemical properties of ceriabased oxides for use in intermediate-temperature SOFCs Solid State Ionics 176 (2005) pp.647-654.

88. Herle J., Senevirate D, McEvoy A, Lanthanide co-doping of solid electrolytes: AC conductivity behaviour, Journal of the European Ceramic Society 19 (1999) 837-841.

89. Dudek $\mathrm{M}$, Ceramic oxide electrolytes based on $\mathrm{CeO}_{2}$ - preparation, properties and possibility of application to electrochemical devices, Journal of the European Ceramic Society (2008) submitted to print.

90. Wang F, Chen S, Cheng S, $\mathrm{Gd}^{3+}$ and $\mathrm{Sm}^{3+}$ co-doped ceria based electrolytes for intermediate temperature solid oxide fuel cells ,Electrochemistry Communications 6 (2004) pp. 743-746.

91. Maricle D.L, Swarm T.E, Karavolis S, Enhanced ceria - a low-temperature SOFC electrolyte, Solid State Ionics 52(1992) 173-178.

92. Liu Y, He T, Wang J, Shu W, The effect of Pr co-dopant on the performance of solid oxide fuel cells with Sm-doped ceria electrolyte, Journal of Alloys and Compounds 389 (2005)pp.317-322 .

93. Dudek M, Ziewiec K, Preparation and the electrolytic properties of $\mathrm{CaO}-\mathrm{Sm}_{2} \mathrm{O}_{3}-$ $\mathrm{CeO}_{2}$ system, Advances in Materials Science 6 (2006) pp. 53-58.

94. Soral P, Pal U, Worrel W, Comparison of power densities and chemical potential variation in solid oxide fuel cells with multilayer and single layer oxide electrolytes, Journal of the Electrochemical Society 145 (1998) pp.99-106.

95. Hirabayashi D, Tomita A, Teranishi S, Hibinio T, Sano M, Improvement of a reduction-resistant $\mathrm{Ce}_{0.8} \mathrm{Sm}_{0.2} \mathrm{O}_{1.9}$ electrolyte by optimizing a thin $\mathrm{BaCe}_{1-\mathrm{x}} \mathrm{Sm}_{\mathrm{x}} \mathrm{O}_{3-\alpha}$ layer for intermediate-temperature SOFCs Solid State Ionics 176 (2005) pp. 881-887.

96. Mitsuyasu H, Nonaka Y, Eguchi K, Analysis of solid state reaction at the interface of yttria-doped ceria/yttria-stabilized zirconia, Solid State Ionics 113115 (1998) pp. 279-284.

97. Horita T, Sakai N, Yokokawa H, Dokiya M, Kawada T, Herle J, Sasaki K, Ceria-zirconia composite electrolyte for solid oxide fuel cells, Journal of Electroceramics 2 (1997) pp. 155-164.

98. Park Y, Yoon H, Wachsman E, Fabrication and characterization of highconductivity bilayer electrolytes for intermediate-temperature solid oxide fuel cells, Journal of the American Ceramic Society 88 (2005) pp. 2402-2408.

99. Wachsman E, Functionally gradient bilayer oxide membranes and electrolytes, Solid State Ionics 152-153 (2002) pp.657-662.

100. Wachsman E, Jayaweera P, Jiang N, Lowe D, Pound B, Stable High Conductivity Ceria/Bismuth Bilayered Electrolytes, Journal of the Electrochemical Society 144 (1997) pp. 233-236.

101. Fergus J, Using chemical sensors to control molten metal processing, The Minerals, Metals and Materials Society 52 (2000) pp. 221-230. 
102. Worrel W, Liu Q, Development of an extended - life oxygen sensor for iron and steel melts Solid State Ionics 40-41(1990) pp. 760-763.

103. Weyl A, Tu S, Janke D, Sensors based on new oxide electrolyte and oxygen reference materials for on-line measurements in steel research, Steel Research 65 (1994) pp.167-172.

104. Subbarao E, Sutter P, Hrizo J, Defect structure and electrical conductivity of $\mathrm{ThO}_{2}-\mathrm{Y}_{2} \mathrm{O}_{3}$ solid solutions, Journal of the American Ceramic Society 48 (1965) pp. 443-446.

105. Ramanarayanan $\mathrm{T}$, Worell $\mathrm{W}$, Limitation in the use of solid state electrochemical cells for high - temperature equilibrium measurements, Canadian Metallurgical Quarterly 13 (1974) pp. 325-329.

106. Fischer W, Janke D, Schulenberg M, Calciumzirkonat als Festelektrolyt bei Temperaturen um $1600^{\circ} \mathrm{C}$ Archiv das Eissenhütenwesen 47 (1976) pp. 525-530.

107. Janke D, Oxygen probes based on calcia-doped hafnia or calcium zirconate for use in metallic melts, Metallurgical Transaction 13B (1982) pp. 227-235.

108. Pandit S., Weyl A, Janke D., High-temperature ionic and electronic conduction in zirconate and hafnate compounds, Solid State Ionics 69(1994) pp. 93-99.

109. Dudek M, Bućko M, Electrical properties of stoichiometric and nonstoichiometric $\mathrm{CaZrO}_{3}$, Solid State Ionics 157(2003) pp. 183-187.

110. Dudek M, Właściwości elektryczne i mechaniczne elektrolitów ceramicznych cyrkonian wapnia - regularny roztwór stały tlenku wapnia w dwutlenku cyrkonu. Materiały Ceramiczne 3 (2002) pp. 11-18.

111. Dudek M, Róg G, Bogusz W, Kozłowska-Róg A, Bućko M, Zych Ł, Calcium zirconate as a solid electrolyte for electrochemical devices applied in metallurgy, Materials Science-Poland 24 (2006) pp 253-260.

112. Tien T.Y, Electrical conductivity in the system $\mathrm{CaZrO}_{3}-\mathrm{ZrO}_{2}$, Journal of the American Ceramic Society 11(1964) pp.430-433;

113. Janke D, Richter H, Low oxygen activities in steel melts - Possibilities and limits of the solid electrolyte measuring technique, Archiv das Eissenhütenwesen 50 (1979) pp.93-100.

114. Liu Q, The development of high temperature electrochemical sensors for metallurgical processes, Solid State Ionics 86-88 (1996) 1037-1043.

115. Dudek M, Róg G, Bogusz W, Bućko M, Kozłowska-Róg A, Kompozytowe elektrolity stałe zawierające $\mathrm{CaZrO}_{3}$ jako elementy ogniw elektrochemicznych stosowanych w metalurgii Kompozyty/Composites 4 (2005) pp. 14-19.

116. Dudek M, Bogusz W, Elektrolity stałe z układu $\mathrm{CaO}-\mathrm{ZrO}_{2}$ jako elementy sond elektrochemicznych stosowanych $\mathrm{w}$ metalurgii, Polski Biuletyn Ceramiczny 91(2005) pp. 159-166. 